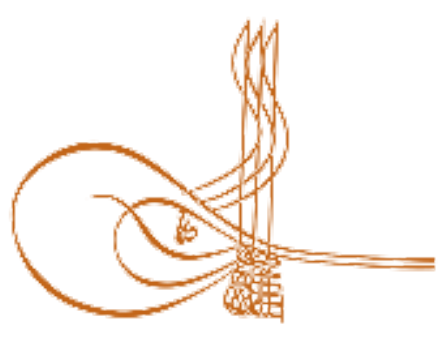

www.turkishstudies.net/education
Turkish Studies - Educational Sciences

eISSN: 2667-5609

Research Article / Araștırma Makalesi

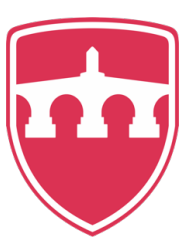

INTERNATIONAL BALKAN

UNIVERSITY

Sponsored by IBU

\title{
Pedagojik Formasyon Alan Yabancı Dil Öğretmen Adaylarının Dönüt Konusundaki Görüşleri ${ }^{1}$
}

Opinions of Foreign Language Trainee Teachers Enrolled in The Pedagogical Formation Program on "Feedback"

\author{
Hanife Güven*
}

\begin{abstract}
Since 2000, growing importance has been attached not only to foreign language education, but also to language teacher education in order to achieve the goals set by the European Union and Council of Europe. In the framework programs prepared for this purpose, "feedback" is one of the most important pillars to be considered in the training and acquisition of professional qualification processes of foreign language teachers. Feedback is indeed a prominent basic tool in determining whether the teaching/learning process has achieved its goal as well as in completing the assessment process. The objective of this study is to obtain the opinions of trainee teachers, regarding feedback, who were graduated from faculties of letters (translation and interpreting, language and literature, culture and literature departments) and who followed pedagogical formation courses in a faculty of education during the 2017-2018 academic year. In this way, we aimed to determine the positive and negative aspects of the feedback they experienced throughout their practical activities at secondary education institutions and their opinions and awareness about feedback. To this end, a "40-item feedback scale" was used. The study group consisted of 133 pre-service teachers who were graduated from various departments of faculties of letters. By subjecting the research data to descriptive statistical analysis, we clarified the trainee teachers' opinions regarding "feedback". In addition, we analysed the results of the distribution concerning the types of feedback received by pedagogical formation students who will work as foreign language teachers; as well as the results related to the frequency of receiving feedback by presenting the frequency and percentage values. To this end, a "40-item feedback scale" was used. The study group consisted of 133 pre-service teachers who were graduated from various departments of faculties of letters. By subjecting the research data to descriptive statistical analysis, we clarified the trainee teachers' opinions regarding "feedback". In addition, we analysed the results of the distribution concerning the types of feedback received by pedagogical formation students who will work as foreign language teachers; as well as the results related to the frequency of receiving feedback by presenting the frequency and percentage values.
\end{abstract}

${ }^{1} \mathrm{Bu}$ makale DEÜ Buca Eğitim Fakültesi tarafından düzenlenen "I. Uluslararası Bilim, Eğitim, Sanat ve Teknoloji Sempozyumu'nda (UBEST-2019, 2-4 Mayıs 2019, İzmir) aynı başlıkla sunulan bildirinin gözden geçirilmiş ve genişletilmiş şeklidir.

* Dr. Öğr. Üyesi, Dokuz Eylül Üniversitesi, Buca Eğitim Fakültesi, Fransız Dili Eğitimi Anabilim dalı Asst. Prof. Dr. Dokuz Eylül University Buca Faculty of Education, French Language Teaching Department ORCID 0000-0002-9166-1271

hanife.guven@gmail.com

Cite as/ Atıf: Güven, H. (2020). Pedagojik formasyon alan yabancı dil öğretmen adaylarının dönüt konusundaki görüşleri, Turkish Studies - Education, 15(2), 877-896. https://dx.doi.org/10.29228/TurkishStudies.40277

Received/Geliş: 09 February/Şubat 2020

Accepted/Kabul: $25 \mathrm{March} /$ Ay 2020

Checked by plagiarism software

Copyright (C) INTAC LTD, Turkey

Published/Yayın: 30 April/Nisan 2020

CC BY-NC 4.0 
Structured Abstract: Since 2000, growing importance has been attached not only to foreign language education, but also to language teacher education by the European Union and Council of Europe. In the framework programs prepared for this purpose, "feedback" is one of the most important pillars to be considered in the training and acquisition of professional qualification process.

The objective of this study is to obtain trainee teachers' opinions on feedback, who were graduated from various faculties of Letters and who took pedagogical formation at faculties of education. In this way, we aimed to determine their thoughts and awareness about feedback through their personal experiences at secondary education institutions.

Theoretical Framework: Feedback is one of the most basic tools to determine whether the teaching/learning process has achieved its goal or not, and also a tool to complete the assessment.

Thorndike (1932) who proposed that the gains ofthe Industrial Revolution should be applied to education in his studies on connectionism, and Pressey (1932) who followed him were the first researchers to emphasize the importance of feedback in education with self-measuring machines. Feedback research, continued with the work of pioneering behaviorist researchers, such as Watson $(1928,1930)$, Pavlov (1928) and Skinner (1958) and accelerated even more after the Second World War. Behaviorism's stimulusresponse-reward components, based on objective behavioral observation, were very effective in providing feedback, especially thanks to computer support, exercises and tests requiring low cognitive skills.

It is accepted that the concept of feedback is introduced into scientific terminology with Norbert Wiener's book Cybernetics or Control and Communication in the Animal and the Machine (1948). Feedback was defined by the same author in 1950 as the ability to adjust future behaviours based on past performance (Wiener, 1950). John B. Carroll, who reviewed in 1989 his article entitled A Model School Learning (1963) 25 years after the publication, emphasized that formative tests, and corrective feedback, should be used when appropriate and feasible. Bloom (1968, 1971), in the Mastery Learning partly based on the work of Carroll, highlighted above all the individualization of the teaching rather than competing the students in order to realize a qualified teaching, and informing the students about the learning contents and objectives, motivating them to participate sufficiently and effectively in the courses as well as providing them with corrections and feedback.

The European Profile for Foreign Language Teachers Education- a Frame of Reference (Kelly et al., 2004) presents 40 items describing key elements in foreign language teacher education. It focusses on 6 items concerning the importance of receiving feedback for trainee teachers in the process of teaching.

As emphasized by Boud and Molloy (2013), recents years have seen many studies on feedback at higher education in different countries, particularly in Scotland (Hounsell, 2007; Hounsell et al., 2008; Nicol and Macfarlane-Dick, 2006; Nicol, 2009); the UK (Rust et al., 2005; Price et al., 2007, 2010; O'Donovan et al., 2016) and Hong Kong (Carless, 2006, 2009; Carless et al., 2011). They identified important features of evaluation activities and feedback practice and claimed that feedback was the most important component of the assessment cycle as far as it concerns the improvement of the quality of teaching and learning. Thus "there has been a tendency to treat feedback as a single notion that must be understood" (Boud and Molloy 2013:700). Researches highlighting the importance of feedback at higher education are also conducted in Turkey (Akkuzu, 2012; Akkuzu \& Uyulgan, 2014; Çimer et al. 2010). Furthermore, some studies focused chiefly on explaining the role and the effects of feedback in micro teaching which rather cocerns the fields such as matematics or science (Saban \& Çoklar, 2013, Ekşi, 2012; Akkuzu, 2012; Akkuzu \& Uyulgan, 2014; Bandura, 1997; Çimer et al., 2010; Kukanauza de Mazeika, 2001; Ananthakrishnan 1993). It is noteworthy that no study has ever been conducted on feedback for initial education of foreign language teachers who received pedagogical formation at faculties of education.

Method: The aim of our research is to determine the opinions and awareness of trainee teachers regarding feedback, as well as to establish the positive and negative aspects of their personal experiences. This research is a descriptive study since it is based on the examination of trainee teachers' opinions on feedback. 
Study Group: The study group consists of 133 trainee teachers who were graduated from various departments (translation and interpreting, language and literature, culture and literature) of faculties of letters and who took pedagogical formation courses at a faculty of education during the 2017-2018 academic year. We note that the majority of these 133 trainee teachers recruited as our representative sample are female students whose number is 99 , whereas the number of male students is 34 . A very large majority of the trainee teachers did their stuies in English (107 out of 133), 16 in German, 7 in French and 3 in other languages (Spanish and Italian) and will become teachers of these languages.

\section{Data collection tool}

a. Feedback Scale: "40-item feedback" scale which was developed by Akkuzu and Uyulgan (2014) was used. The construct validity of the scale was determined by Exploratory Factor Analysis (EFA) and Confirmatory Factor Analysis (CFA). The factor load values of the items in the scale were high and ranged from 0.48 to 0.69 . The scale consists of two factors: "professional development" and "anxiety" and a total of 40 items. Confirmatory Factor Analysis (CFA) which confirms that the scale fit perfectly to the two-factor structure was conducted.

The reliability coefficients of the items related to professional development and anxiety factors of the feedback scale were as high as 0.947 and 0.835 , respectively.

b. Personal Information Form: In this form, are such variables as the type of feedback, frequency of receiving feedback etc., that are used for identifying trainee teachers' opinions on their feedback experiences. These variables are at the top of the feedback scale.

Data Analysis: By subjecting the research data to descriptive statistical analysis techniques, we clarified the foreign language trainee teachers' opinions regarding "feedback". Additionaly, we analysed the results of the distribution of the types of feedback received by pedagogical formation trainee teachers who will work as foreign language teachers; as well as the frequency of feedbacks by presenting the frequency and percentage values.

\section{Results}

- The majority of foreign language trainee teachers (101) received feedback after each lesson. 11 trainee teachers stated that they did not receive any feedback.

- The majority of trainee teachers (102) stated that they received oral feedback, 12 written feedback and 1 received both written and oral feedback.

- The majority of trainee teachers (107) received positive feedback. The number of negative feedback is 8.14 trainee teachers stated that they received both positive and negative feedback.

- The majority of trainee teachers (87) stated that faculty members participated in lecture presentations and 42 trainee teachers stated that faculty members did not participate.

Conclusions and Proposals: It is satisfactory to see that the trainee teachers who experienced feedback largely through their personal and concrete educational activities believe deeply in its benefits. Another interesting aspect is the fact that it exposess the predominance of monolingualism in the Turkish education system.

Foreign languages trainee teachers are supposed to have a period of teaching observation and practice at a school (4 hours weekly). Nonethless, it is observed that trainee teachers who teach other languages than English have difficulty in following the obligatory hours of weekly courses or finding a relevant course for practice. Because either no course of that language is available or the course hours are insufficent ( 2 hours per week for the second foreign language). We believe that in order to promote and encourage linguistic and cultural diversities, additional foreign languages should be timetabled and taught at secondary schools alongside English. Furthermore, for the sake of efficiency, longer time periods should be allocated to them.

Keywords: Foreign Language Education, Teacher Training, Feedback,Teaching Practice

Öz: 2000 yllından bu yana Avrupa Birliği ve Avrupa Konseyi belirledikleri hedeflere ulaşmak için, eğitimle ilgili çalışmalarında yabancı dil eğitiminin yanı sıra, yabancı dil öğretmenlerinin eğitimine de giderek daha fazla önem vermektedir. Bu amaçla hazırlanan çerçeve programlarda yabancı dil öğretmenlerinin belli bir mesleki yeterlilik kazanması için üzerinde durulması gereken en temel noktalardan birinin dönüt/geri bildirim olduğu dikkat çekmektedir. Dönüt gerçekten de öğretme/öğrenme sürecinin hedefine ulaşıp ulaşmadığını saptamaya yarayan ve ölçme-değerlendirmeyi tamamlayan en temel araçlardan biridir.Bu çalışmanın amacı yabancı dil eğitimi veren çeşitli fakültelerden mezun olup öğretmen eğitiminin verildiği eğitim fakültelerinde 
pedagojik formasyon alan öğretmen adaylarının öğretmenlik uygulamaları sırasında etkinlikleri ile ilgili aldıkları dönütler konusundaki görüşlerini almaktır. Böylece öğretmen adaylarının öznel gerçekliklerinden hareketle, dönüt konusunda somut olarak edindikleri deneyimin olumlu ve olumsuz yanlarını ve dönüt konusundaki düşüncelerini ve farkındalıklarını belirlenmesi amaçlanmaktadır. Bu amaç doğrultusunda 40 maddelik bir geri bildirim ölçeği kullanılmıştır. Araştırmanın çalışma grubunu eğitim fakülteleri dışında yabancı dil eğitimi veren çeşitli fakültelerden mezun olup 2017-2018 öğretim yılında bir eğitim fakültesinde pedagojik formasyon almakta olan 133 öğretmen adayı oluşturmaktadır. Araştırma verileri betimsel istatistik teknikleri kullanılarak çözümlenmiş, ögretmen adaylarının dönüt hakkındaki düşünceleri ortaya çıkarılmış ve yabancı dil öğretmen adayı olan pedagojik formasyon öğrencilerinin öğretmenlik uygulamalarına yönelik aldıkları dönüt türlerinin dağılımı ve dönüt alma sıklıkları frekans ve yüzde değerler açısından verilerek sonuçlar tartışılmıştır.

Anahtar Kelimeler: Yabancı Dil Eğitimi, Öğretmen Eğitimi, Dönüt, Öğretmenlik Uygulaması.

\section{Giriş}

Eğitim politikalarını yönlendiren uluslararası bir istatistik olan PISA ${ }^{2}$ sonuçları yayımlanır yayımlanmaz her ülkede eğitim sistemi ile ilgili tartışmalar ve sorgulamalar başlarken anketlerde değerlendirilen üç alanda da OECD ortalamasının bir hayli altında olmamız ülkemiz kamuoyunda pek tepki uyandırmamaktadır. Oysa PISA sonuçları dayanışma yerine rekabet üzerine kurulu eğitim sistemimizde, sınıfının, okulunun ya da hatta ülkesinin birincisi olmanın pek de anlamlı olmadığını bariz bir biçimde göstermekte ve gençlerimize sunulan eğitimin etkililiği ve niteliği konusunda düşünmeye itmektedir. Bu durum eğitimin tüm seviyeleri için geçerlidir. Öte yandan PISA soruşturmasında hemen hemen her üç alanda en ön sıralarda yer alan Singapur, Japonya, Estonya, Finlandiya, Hong Kong, Kanada vb. ülkelere baktığımızda eğitim sistemlerinin en önemli bileşeninin öğretmen eğitimi olduğuna tanık olmaktayız.

Milli Eğitim Bakanlı̆̆ı tarafından yayımlanan Öğretmenlik Mesleği Genel Yeterlikleri (2017: 2) kitapçığında nitelikli bir öğretmen eğitimi sunmanın önemi şöyle vurgulanmaktadır:

"Son yıllarda, gelişmişliğin eğitime ayrılan kaynaklar yanında eğitimin niteliği ile olan ilişkisi ön plana çıkmakta ve çalışmalar bu alanda yapılmaktadır. Eğitim alanında gerçekleştirilecek her türlü değişim eğitimin bizzat uygulayıcısı olan öğretmenlerin elinde yeniden biçimlenerek anlam kazanmaktadır. Dolayısıyla eğitimin niteliğine doğrudan ve en önemli etkiyi öğretmenler yapmaktadır. Bu nedenle yüksek nitelikli ögretmenlere sahip olmak eğitim alanında yapılacak değişimler için bir ön şart niteliğindedir.”

Öte yandan 2000 yılından bu yana Avrupa Birliği'nin eğitimle ilgili çalışmalarında, bir yandan "çok küçük yaşlardan itibaren en az iki yabancı dil öğretilmesi" (Conclusions, 2002: 20) önerilirken, öte yandan yabancı dil öğretmenlerinin eğitimine de giderek artan bir önem verilmekte ve Avrupa Birliği'nin belirlediği hedefleri somutlaştırmak için yabancı dil öğretmenlerinin yadsınamaz rolü vurgulanmaktadır (Kelly et al., 2004). Gerçekten de ilk ve ortaöğretim düzeyindeki öğrencilerin iyi yetişmesi her şeyden önce öğretmenlerin iyi yetişmiş olmasına bağlıdır. $\mathrm{Bu}$ nedenle öğretmen adaylarının meslek hayatına atıldıklarında karşılarına çıkacak sorunlarla baş edebilmek için hizmet öncesi dönemde nitelikli bir eğitim almış olmaları ve alanlarında yeterince deneyim kazanmış olmaları gerekir (Yüce 2019a). Bu anlamda Okul Deneyimi ve Öğretmenlik Uygulaması derslerinin önemi yadsinamaz.

\footnotetext{
${ }^{2}$ Pek çok ülkede zorunlu eğitimin sonu olan 15 yaş sınırındaki öğrencilere 3 yılda bir uygulanan Uluslararası Öğrenci Değerlendirme Programı (Programme for International Student Assessment) PISA verileri gelecek kuşaklarımızın hayata atıldıktan sonra Okuma, Matematik ve Fen Bilgisi alanlarında, okul bilgisinin yanı sıra, özel, kamusal, mesleki ve eğitsel alanlarda karşılarına çıkacak sorunlarla baş etmeye hazır olup olmadığı ve aldığı eğitimin dünya ülkelerinin gençlerine kıyasla yeterliliği konusunda bilgi sahibi olmamızı sağlamaktadır. Öte yandan PİSA sonuçları düşük olan Fransa'da Eski Eğitim bakanlarından filozof Luc Ferry PISA'nın eğitim sistemini değil öğrencilerin performansını ölçtüğünü, oysa öğrenci performanslarının da okuldan bin kez daha fazla ailelerle ilgili olduğunu açıklayarak epeyce tepki almıştır (Ferry, 2017).
} 
Bilindiği gibi, Avrupa'da yoğun işgücü transferinin etkisiyle yabancı dil alanında yetişkin eğitiminin önem kazanmaya başladığı 70'li yıllardan bu yana kuramsal olarak öğrenci merkezli eğitime yönelinmiş, öğrenme ve öğretme süreçleri tek yanlı değil; bilişsel, duyuşsal ve sosyal boyutlarıyla dinamik bir süreç olarak ele alınmaya başlamıştır (Epstein, 1993; Goleman, 1996; Askew \& Carnell, 1998). Bu süreçte öğrenmenin mümkün olduğunca bireyselleştirilmesinin ve düzenli olarak öğrenciye dönüt verilmesinin önemi üzerinde durulmaktadır. Bilişsel Bilimler alanında kaydedilen son gelişmeler de öğrenmenin dört temel direğinden birinin zamanında ve açık seçik olarak verilen dönüt olduğunu ortaya koymuştur (Dehaene, 2018). Ancak üniversitelerde öğrenci sayısının giderek artması (Boud \& Molloy 2013: 699) programların pek esnek olmayışı, öğretim elemanlarının haftalık ders saatlerinin fazla olması nedeniyle kuramsal derslerde dönütlerin de giderek azaldığı (Hounsell 2007), değerlendirmelerde düzey belirleme ve başarı tespitiyle yetinildiği dikkat çekmektedir (Puren et al., 1998: 173; Arslan, 2016: 356). Nitekim ülkemizde değerlendirme sisteminin bir yarıyıl ve bir final ve bazen de bir ödev notuna dayalı olması dönüte pek firsat tanımamaktadır. Bu nedenle öğretmen adaylarının hizmet-öncesi süreçte en azından uygulama etkinlikleri sırasında etkili bir biçimde dönüt almaları ve bu alanda deneyim kazanmaları hizmete atıldıklarında verecekleri eğitimin niteliği açısından hayati önem taşımaktadır.

\section{Kavramsal çerçeve}

"Dönüt" dilimizde İngilizce'deki feedback (to feed + back) teriminin karşılığı olarak kullanılmakta, sözcüğün TDK'da tanımı "geri bildirim" olarak verilmektedir. "Geri bildirim" ise "gönderilen bilgi veya talimatın alıcıda yaptığı etkiye ilişkin edinilen bilgi, dönüt" olarak tanımlanmaktadır. Bilindiği gibi öğrenme-öğretme sürecinin en temel öğesi hedeftir. Hedefe ne kadar yaklaşıldığı ise ölçme-değerlendirme ile saptanır. Bu anlamda dönüt öğrenme sürecinde öğrencinin hedeflediği seviye ile bulunduğu seviye arasındaki farkın kapatılması için en gerekli faktördür.

Georges ve Pansu (2011) derleme makalelerinde Psycinto veri tabanında dönüt üzerine 2000'den fazla çalışma olduğunu belirtmektedirler. Gerçekten de belli başlı çalışmalardan hareketle dönüt olgusunun tarihçesine bakacak olursak konu ile ilgili araştırmaların XX. yüzyıl başlarında sibernetik alanında başladığı, eğitim alanında Thorndike'ın (1932) bağlaşımcılık adıyla anılan çalışmalarıyla gündeme geldiği görülmektedir. Sanayii devriminin gelişmelerinin eğitim alanında yansımasını öngören Thorndike ve onun izinde giden Pressey (1932: 668-672) kendi kendine ölçme makinalarıyla eğitimde dönütün önemini vurgulayan ilk araştırmacılar olmuşlardır. Dönüt ile ilgili araştırmalar Watson (1928, 1930), Pavlov (1928) ve Skinner (1958) gibi davranışç1 araştırmacıların bilhassa kedi, köpek, fare, güvercin, maymun gibi hayvanlar üzerine çalışmalarıyla (Bransford et al., 2005) sürmüş, bilhassa İkinci Dünya savaşından sonra daha da hız kazanmıştır. Davranışların tarafsız bir açıdan gözlemlenmesi üzerine kurulan Behaviorizm'in uyarıcı-cevapödül bileşenleri bilhassa bilgisayar desteğiyle ve düşük seviyelerde bilişsel yeterlik gerektiren alıştırma ve testlerle dönüt alınabilmesi konusunda çok etkili olmuştur (Skinner, 1958: 969-977). Gerçekten de makineler aracılığıyla kendi kendini değerlendirerek elde edilen cevap hedeflenen düzeye göre bir dönüttür ve dönüt bu şekliyle biçimlendirici değerlendirmenin de en temel öğesidir. Ancak daha üst düzeylerdeki bilişsel süreçler için öğretmenin dönütü elzemdir.

Dönüt kavramının bilimsel terminolojiye Wiener'in Cybernetics or Control and Communication in the animal and the Machine (1948) kitabı ile girdiği kabul edilmektedir. Dönüt aynı yazar tarafindan daha sonra öğrenmeyle ilişkilendirilerek "geçmişteki performanstan hareketle gelecekteki davranışları ayarlayabilme özelliği" olarak tanımlanmıştır (Wiener, 1950: 33). Paquette'e göre (1987: 8) ise dönüt bir kontrol sürecidir ve üç alt-süreci vardır : "bilgi, değerlendirme ve tepki”.

Çalışmalarının çoğunda okulda öğrenmenin önemine dikkat çeken Carroll "A model of school learning" (1963) makalesinin yayımlanışından 25 yıl sonra gözden geçirdiği çalışmasında (1989: 26-31) "Öğretmenler bir sınıf yöneticisi olarak, zeki ve yeterli olmanın yanı sira, 
ögrettikleri dersin konusuna da hakim olmalıdır. (..) Biçimlendirici testler, düzeltici dönütler vb uygun olduğunda ve uygulanabilir görüldügünde kullanılmalıdır." demiştir.

Bloom (1968: 1-11, 1971: 47-63) Carroll'un çalışmalarına dayanarak sunduğu Tam Öğrenme Modeli'nde nitelikli bir öğretimin gerçekleştirilmesi için her şeyden önce öğrencilerin birbirleri ile yarıştırılmasından çok öğretimin bireyselleştirilmesi üzerinde durmuştur. Bloom ögrencilerin öğrenme içerikleri ve hedefler konusunda bilgilendirilmesi, yeterince güdülenmesi ve derslere etkili katılımlarının sağlanmasının yanı sıra, kendilerine düzeltme ve dönüt verilmesi gerektiği üzerinde durmuştur. Bir ünite tam öğrenme ölçütleriyle işlenip bittikten sonra yapılan biçimlendirici değerlendirme sonucunda başarıll olan öğrencilere daha geliștirici ve zenginleștirici etkinlikler verilirken, başarısız olanlara düzeltme ve dönüt sağlanarak eksikleri giderilmelidir. Arslan (2016: 199-205) da aynı konuya dikkat çekmektedir.

Askew ve Lodge (2000: 1-17) veriliş ve alınış bakımından dönütleri "hediye, pinpon ve çevrim" olarak nitelendirdikleri üç türe ayırırlar. Dönüt tek yanlı bilgi verdiğinde hediyedir, dönütü alanın bilgiyi oluşturup dönüt istemesi söz konusuysa pinpondur, öğrenme süreciyle özdeşleştirildiği ve alan ile veren arasında sürece yönelik bilgi alışverişi, sorumluluk ve güç paylaşımı söz konusuysa çevrimdir. Yazarlar öte yandan hediye dönütü davranışçı, pinpon dönütü yapılandırmacı ve çevrim dönütü de sosyokültürel eğitim anlayışı ile bağdaştırmaktadır.

Hell-Nieuwenhuis (2012: 57) araştırmasında öğrencilerin büyük çoğunluğunun hem doğru yanıt verdiklerinde, hem de yanlış yanıt verdiklerinde öğretmenin müdahele etmesini ya da açıklama yapmasını takdir ettiklerini söylediklerini belirtmektedir. Boud ve Molloy (2013: 6) dönütü bir bilgi edinme süreci olarak görmektedirler. Bu süreçte öğrenciler herhangi bir çalışma için uygun normlar ile kendi yaptıkları çalışmaların nitelikleri arasındaki benzerlik ve farklılıkları değerlendirirler.

Günümüzde Bilişsel Nöroloji çalışmaları da öğrenmenin dört temel direğini dikkat, aktif katılım, dönüt ve pekiştirme olarak ortaya koymaktadır. Etkili ve verimli bir öğrenme için öğrencide merak uyandırmak, onun konuya odaklanmasını, dersin işlenişine aktif olarak katılmasını, sağlamak esastır. Nitelikli ve net bir dönüt öğrencinin yaptığı yanlışı anlamasını sağlarken öğrenmenin hızını etkilemekte ve öğrenmeyi kolaylaştırmaktadır. Öte yandan beyin uyurken de çalıştığı için öğrencinin yeterli uykuyu almasını sağlamak ve öğrenilecek konuyu belirli aralıklarla tekrar ederek pekiştirmek gerekir (Dehaene, 2018: 12-27). Görüldüğü gibi dönüt vermek öğrenme hedefine ulaşmayı hızlandırmak ve kolaylaştırmak için en vazgeçilmez öğelerden biridir.

Avrupa'daki yabancı dil öğretmenlerine yönelik olarak hazırlanan başvuru çerçevesinde de (Kelly ve diğerleri, 2004) öğretmen adaylarının gerek kuramsal eğitimlerinde, gerekse öğretmenlik uygulaması ve öğretmenlik deneyimleri sürecinde dönüt almalarının önemine dikkat çekmektedir. Dört temel bölümden ve 40 maddeden oluşan çerçeve programının altı maddesinde dönütün gerekliliği vurgulanmaktadır.

Dönüt türleri de araştırmacıların ilgisini çeken bir öğedir. Askew ve Lodge’a göre (2000: 7) günlük kullanımda olumlu dönüt öğrencinin performansıyla ilgili memnuniyete, olumsuz dönüt ise eleştiriye ve değişim ihtiyacına işaret eder. Dönüt alan kişinin olumlu dönütü kabul ederken olumsuzdan korktuğu kabul edilir. Georges ve Pansu (2011) dönütün sıklıkla "güdülüme ve başarının anahtarı" olarak kabul edildiğini belirttikten sonra "basit dönüt" olarak da adlandırılan doğru yanıt dönütü konusunda bilgi vermektedirler. Brophy ve Good (1970) sessiz (başla onaylama), sözlü, olguya dayalı, not ya da başarı durumu belirten ama öğrencinin kişiliğiyle ilgili hiçbir bilgi vermeyen dönütleri bu kategiye koymuşlardır. Butler ve Vinne (1995: 275) bu dönütün, bilginin türü "ister belli bir alanla ilgili, ister üstbilişsel, ister kendi yaptığı etkinlik ve stratejiler ile ilgili inançları konusunda olsun öğrenenin bilgiyi onaylamasını, ona eklemeler yapmasını, değiştirmesini, uyarlamasını ya da bellekte yeniden yapılandırmasını" sağladığını belirtmektedirler. Lyster ve Ranta (1997: 37-66) ilköğretimde gözlemledikleri yabancı dil sınıflarındaki etkinliklerde 
6 tür sözlü dönüt belirlemişlerdir : yanlış bir formun yanlış olduğu söylenerek açıkça düzeltilmesi, yanlış bir formun örtük bir şekilde düzeltilmesi, öğrenciden açıklama istenmesi, üstdilsel (dilbilgisel) ipuçları verilmesi, doğru formun sorular yardımıyla buldurulması, yanlışın vurgulanarak yinelenmesi. Elbette verilecek dönütün yapılan dil etkinliğiyle, hedefle, kullanılan araç-gereç ve tekniklerle yakından ilişkili olduğu unutulmamalıdır. Ancak yazarların yaptıkları sınıf gözlemleri, dönütün öğretmenler tarafından daha çok örtük bir biçimde öğrencinin yanlışını düzeltmek amacıyla kullanıldığını ortaya koymuşlardır. Yazarlar son dört seçeneğin öğrenciyi yanlışını onarmaya daha çok teşvik ettiği görüşündedirler. Öte yandan sınıfta öğrencilerin dışında yabancıların bulunmasının ve not tutulmasının dahi ders ortamını etkilediğini göz ardı etmemek gerekir.

Dönütün “duygusal işlevi” (Bosc-Miné 2014: 343) ve verilme biçimi de dönüt kadar önemlidir. Dönüt verilirken öğretmen adayının dinlemeye hazır olduğundan emin olmalı, sağlıklı ve samimi bir iletişim kurmalıdır.

Boud ve Molloy (2013) tarafindan da vurgulandığı gibi, son yıllarda, farklı ülkelerde, bilhassa İskoçya'da (Hounsell, 2007; Hounsell et al., 2008; Nicol ve Macfarlane-Dick, 2006; Nicol, 2009); İngiltere'de (Rust et al., 2005; Price et al., 2007, 2010; O’Donovan et al., 2016) ve Hong Kong'da (Carless, 2006, 2009; Carless et al., 2011) yüksek öğretimde dönüt konusunda ilginç çalışmalar yayımlandığı görülmektedir. Bu çalışmalar daha çok değerlendirme faaliyetleri ile dönüt arasındaki ilişkiler üzerinde durmaktadır. Boud ve Molly (2013: 700) bu çalışmalarda dönütün "anlaşılması gereken tek bir kavram olarak görülme eğilimi" olduğunu belirtmektedir. Türkiye'de de son 10 yıldır yüksek öğretimde dönütün önemine dikkat çeken araştırmalar yapılmaktadır (Akkuzu, 2012; Akkuzu ve Uyulgan, 2014; Çimer et al., 2010, Saban ve Çoklar, 2013). Öte yandan bu konudaki araştırmaların daha çok mikroöğretime dayalı olduğu ve fen-matematik gibi temel alanlara yönelik olarak yürütüldüğü görülmektedir (Kukanauza de Mazeika, 2001; Saban ve Çoklar, 2013; Ekşi, 2012; Ananthakrishnan, 1993). Çalışmamızın diğer araştırmalara göre farkı eğitim fakültelerinde pedagojik formasyon alan yabancı dil öğretmen adaylarına yönelik olmasıdır.

Bu çalışmada dönütün yüksek öğretimdeki yerini araştırmak üzere Pedagojik Formasyon eğitimi alan yabancı dil öğretmen adaylarının kuramsal eğitimlerindeki dönütten ziyade, öğretim uygulamalarına, öğrenme - öğretme deneyimlerine yönelik olarak aldıkları ve verdikleri dönütler ve bunların niteliğinin ve çeşitliliğinin sorgulanması hedeflenmiştir. $\mathrm{Bu}$ amaç doğrultusunda aşağıdaki sorulara yanıt aranmıştır:

1. Öğretmen adayının öğretmenlik uygulamalarına devam saatlerinin dağılımı nasıldır?

2. Öğretmen adayının staj dersi sunum saatlerinin dağılımı nasıldır?

3. Uygulama öğretmeni ve öğretim üyelerinin dersi izleme dağılımları nasıldır?

4. Öğretmen adaylarının öğretmenlik uygulamaları sırasında aldıkları dönüt sıklık dağılımı nasıldır?

5. Öğretmen adaylarının öğretmenlik uygulamaları sırasında aldıkları dönüt türlerinin dağılımı nasildır?

6. Öğretmen adaylarının öğretmenlik uygulamaları sırasında aldıkları dönüt puanları alt boyutlar dikkate alındığında ortalama ne düzeydedir?

\section{Yöntem}

Araştırmamızın amacı kendi gelecekleri konusunda düşünen, ona katılan ve meslek yaşamlarında alacakları kararların önemi konusunda bilinçlenmiş bireyler olarak öğretmen adaylarının kendi öznel gerçekliklerinden hareketle uygulama etkinlikleri sırasında aldıkları dönüt konusunda somut olarak ne düşündüklerini, bu konuda ne kadar bilinçli olduklarını, deneyimlerinin olumlu ve olumsuz yanlarını belirlemektir. Araştırma, öğretmen adaylarının dönüt hakkındaki görüşlerinin incelenmesine ilişkin betimsel araştırma türündedir. 


\section{Araştırmanın Çalışma Grubu}

Araştırmanın çalışma grubunu Eğitim Fakültesi dışında yabancı dil eğitimi veren fakültelerden mezun olup öğretmen olmak üzere 2017-2018 öğretim y1lında bir devlet üniversitesinin Eğitim Fakültesinde Pedagojik Formasyon eğitimi alan öğretmen adayları oluşturmaktadır.

Tablo 1: Öğretmen Adaylarının Cinsiyet Dağılımı

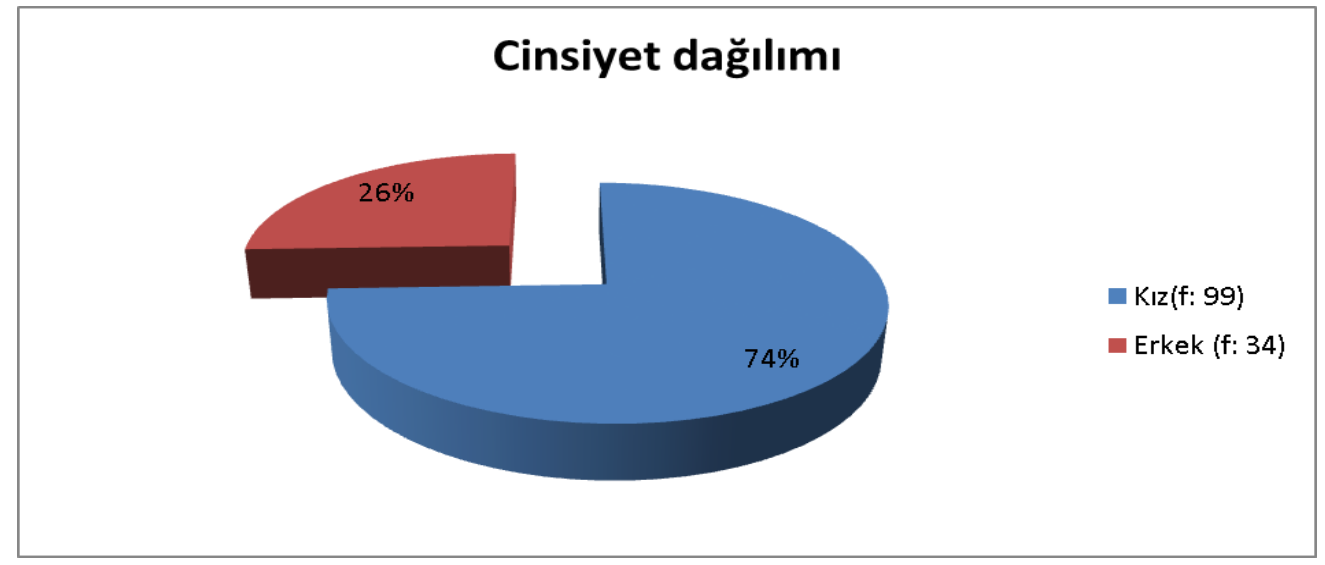

Tablo 1 araştırmaya katılan öğretmen adaylarının cinsiyet dağılımını göstermektedir. Örneklemimize giren toplam 133 öğretmen adayının büyük çoğunluğunu kız öğrenciler (N:99) oluşturmaktadır. Sadece 34 erkek öğrenci bulunmaktadır.

Tablo 2 : Öğretmen Adaylarının Okudukları Bölüme İlişkin Dağılım

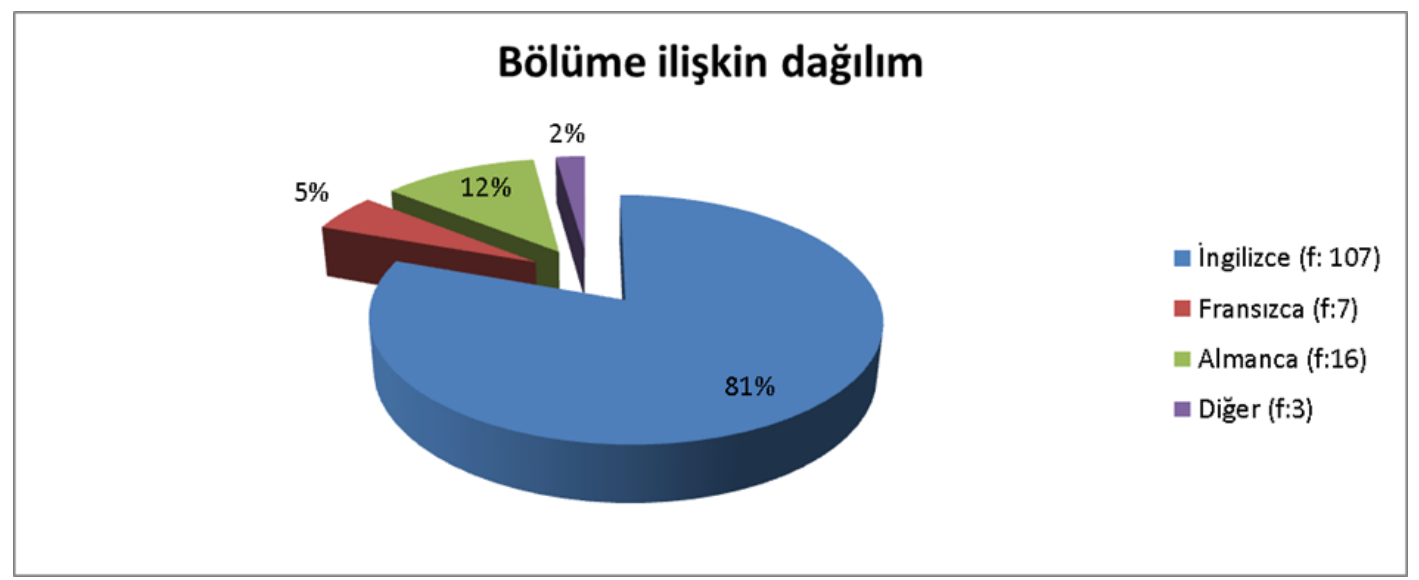

Öğretmen adaylarının mezun oldukları dil bölümünü gösteren Grafik 2'ye baktığımızda büyük çoğunluğun İngilizce (N:107) eğitim veren bölümlerden geldiği anlaşılmaktadır. Bunu Almanca (N:16) izlemekte, daha sonra Fransizca (N:7) gelmektedir. Sayıca en az olan grup (N:3) diğer dillerden (İspanyolca ve İtalyanca) mezun olup bu dillerin öğretmeni olmak üzere programı izleyenlerdir.

Araştırma verileri toplanırken Morrow'un (2008) belirttiği sosyal araştırmalarda uyulması gereken etik kurallara uyulmuştur (katılımcının rızasını alma, araştırma hakkında bilgi verme, gizlilik ve özel hayata saygı vb.). 


\section{Veri Toplama Aracı}

\section{a. Geri bildirim Ölçeği:}

Araştırmada Akkuzu ve Uyulgan (2014) tarafindan geliştirilen Geri bildirim ölçeği kullanılmıştır. Ölçeğin yapı geçerliği Açımlayıcı Faktör Analizi (AFA) ve Doğrulayıcı Faktör Analizi (DFA) ile tespit edilmiştir. AFA sonucu ölçekteki maddelerin faktör yük değerleri yüksek olup 0.48 ile 0.69 arasındadır. Ölçek "Mesleki gelişim" ve "Kaygı" olmak üzere iki faktör ve toplam 40 maddeden oluşmaktadır. Doğrulayıcı Faktör Analizi (DFA) yapılmış ölçekte maddeler iki faktörlü yapıya mükemmel derecede uyum sağlamaktadır. Ölçeğin iki faktörlü yapıya uygun olduğunu gösteren doğrulayıcı faktör Analizi (DFA) yapılmıştır.

Geri bildirim ölçeğinin mesleki gelişim ve kaygı faktörlerine ait maddelerinin güvenirlik katsayıları Akkuzu ve Uyulgan (2014) tarafından sırasıyla 0.947 ve 0.835 olarak hesaplanmış olup yüksek güvenirliğe sahip olduğu tespit edilmiştir. Araştırma öğretmen adaylarının dönüte ilişkin düşüncelerini ortaya koyan betimsel nitelikte bir çalışma olduğundan ayrıca bir güvenirlik hesaplamasına gerek duyulmamıştır.

\section{b. Kişisel Bilgi Formu:}

$\mathrm{Bu}$ formda öğretmen adaylarının öğretim deneyimleriyle ilgili yapılan geri bildirimlere ilişkin görüşlerini almak amacıyla geri bildirim türü, geri bildirimi alma sıklı̆̆ 1 vb. değişkenleri yer almaktadır. Kişisel bilgi formundaki bu değişkenler geri bildirim ölçeğinin başında yer almaktadır.

\section{Veri Analizi}

Çalışmada betimsel istatistik teknikleri kullanılarak öğretmen adaylarının geri bildirime ilişkin düşünceleri aritmetik ortalama, minimum ve maksimum değerler hesaplanarak verilmiştir. Öğretmen adaylarının geri bildirim ölçeğinde yer alan maddelere ilişkin verdikleri cevaplar ölçeğin alt boyutları için ayrı puanlar halinde hesaplanmış ve puanlanmıştır. Kişisel bilgi formunda yer alan değişkenlere ilişkin verilerin düzenlenmesinde frekans dağılımı ile birlikte pasta ve sütun grafikler aracılığılla betimsel olarak sunulmuştur.

\section{Bulgular ve tartışma}

Verilerin incelenmesi sonucunda öğretmen adaylarının verdiği yanıtlar okul deneyimleri sırasında aldıkları dönütle ilgili kendi deneyimleri ve düşünceleri konusunda ilginç bilgiler ortaya koymaktadır. Bu veriler aşağıda görselleştirilerek tablolar halinde sunulmuştur : 
Tablo 3 : Staj Dersi Devam Saati

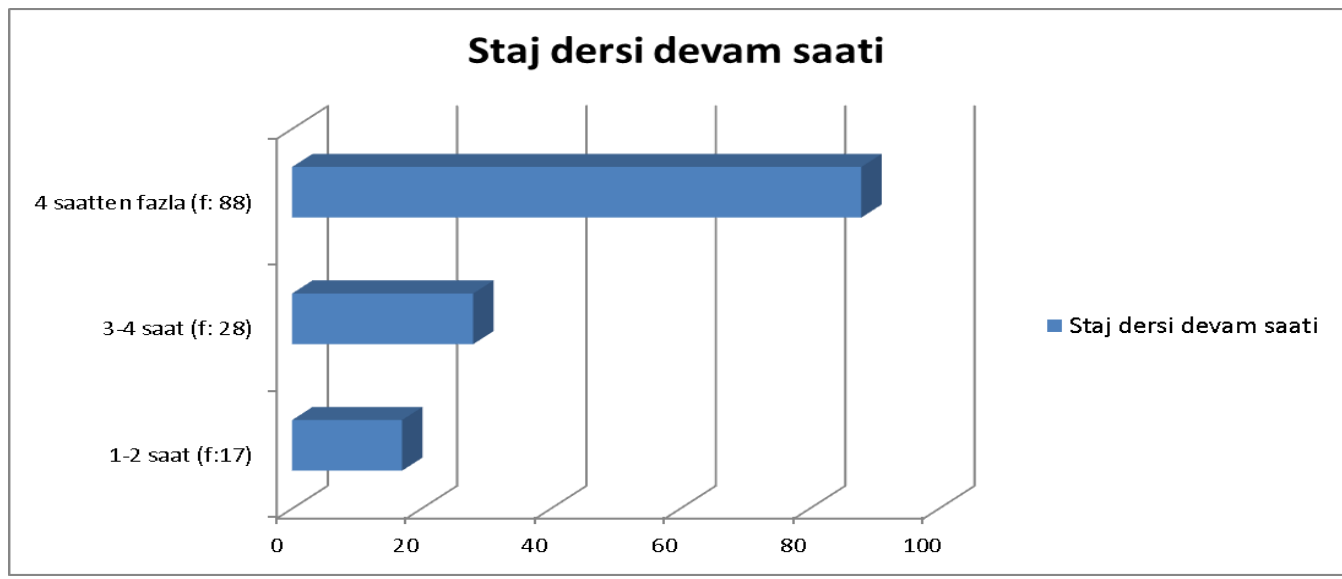

İzmir valiliği İl Milli Eğitim Müdürlüğü’nün 26.06.2018 tarihli Öğretmenlik Uygulama Yönergesi'nde Uygulama öğrencisinin haftada 6 saat ders izlemekle yükümlü olduğu belirtilmektedir. Nitekim Grafik 3'e bakıldığında öğretmen adaylarının çoğunluğunun (88) haftada 4 saatten fazla ders izlediği görülmektedir. Ancak 28 öğrenci sadece 3-4 saat, 17 öğrenci ise haftada sadece 1-2 saat ders izleyebilmiştir. Bu sayı düşük olsa da öğrenci açısından bakıldığında yetersiz görünmektedir. Bu durum İngilizce dışındaki yabancı dillerin azlığından ya da ikinci yabancı dil olarak sunulmasından kaynaklanmaktadır. İkinci yabancı dillerin haftalık ders saati sadece 2'dir.

Tablo 4: Staj Dersi Sunum Saati

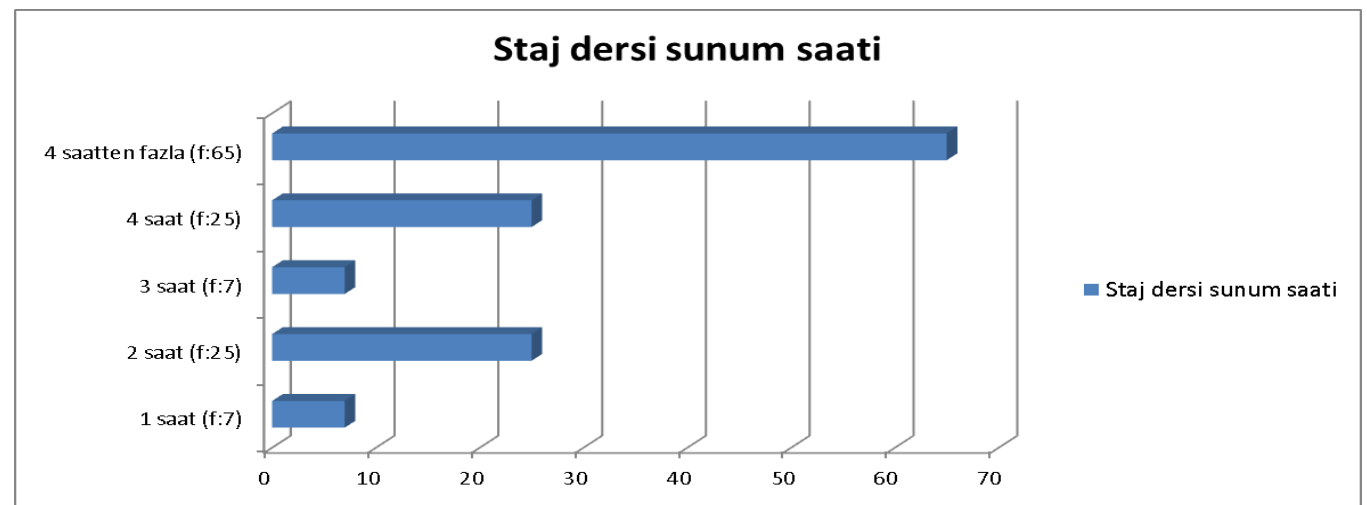

Staj dersi sunumu ile ilgili olan Grafik 4 'te öğretmen adaylarının büyük çoğunluğunun (90) ortalama 4 saat ya da daha fazla sunum yapmış oldukları görülmektedir. Nitekim yukarda sözünü ettiğimiz Öğretmenlik Uygulama Yönergesi’nde ders saatleri ile ilgili açıklama "Öğretmenlik uygulamalarının zaman ve süresi”" başlığı altında şu şekildedir:

"Öğretmenlik uygulaması dersi iki dönem süre ile haftada 6 (altı) ders saatidir. Her bir dönemde uygulama öğrencisi uygulama öğretmeninin gözetiminde farklı haftalarda olmak üzere en az 4 (dört) defa fiilen ders anlatır. (...) Uygulama öğrencisinin fiilen anlatacağı ders saati, ilgili dersin haftalık ders çizelgesinde ders saati 1-2 saat olanlarda en az toplam 14 (on dört), 3 ve üzeri olanlarda ise toplam 24 (yirmi dört) saatten az olmayacak şekilde planlanır" 
39 öğrencinin 4 saatin altında sunum yapmış olmasının da, yine yukarda belirttiğimiz İngilizce'nin dışındaki dillerin ders saati açısından azlığından kaynaklandığı düşünülmektedir. Mikro-öğretim alanında yapılan bir araştırmada öğretmen adayı ilk sunumunda çok heyecanlı olduğunu, sesini bile ayarlamakta zorluk çektiğini, ama aldığı dönütler sayesinde ikinci sunumunda heyecanının azaldığını ve jestlerini daha iyi kontol ettiğini belirtmiştir (Saban ve Çoklar, 2013). Bu nedenle öğretmen adayının yapacağı sunum sayısının artırılması deneyim kazanması açısından önemlidir.

Tablo 5: Uygulama öğretmeni ders izleme frekansı

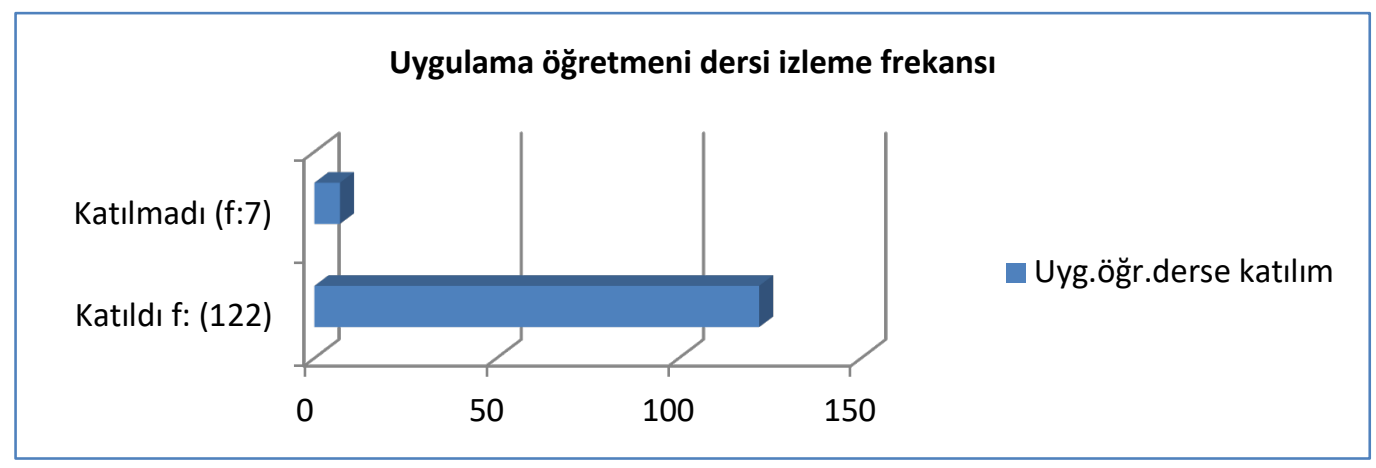

Grafik 5 öğretmen adaylarının büyük çoğunluğunun (122) sunumlarının uygulama dersi öğretmenleri tarafından izlendiğini göstermektedir. Öğretmen adayının, aldığı dönütler 1şığında kendini sorgulayacağ 1 , eksiklerini tamamlamaya başlayacağ 1 , bir tür kendini inşa edeceği düşünülürse, 7 öğrencinin uygulama öğretmeninden dönüt alamamış olması üzüntü vericidir.

Sayıları az da olsa dershanelerde ya da bazı özel kurslarda ders vererek deneyim kazanmış öğretmen adaylarının sunumları deneyimsiz adaylara göre daha iyi olduğu bilinen bir gerçektir, bu tür durumlarda dahi olumlu dönütlerin yararı yadsınamaz. Zira Öğretmenlik Uygulaması dersindeki sunumların amacı doğrudan biçimlendirme ya da yetiştirmedir. Gerçekten de dönüt ile verilen bilgiler sadece alanla ilgili değil, öğretme sürecinin öğrenme ortamları, materyel, sınıf ve zaman yönetimi yönetimi, öğrenci-öğretmen ilişkileri, beden dili gibi en genelden en özel ders konusuna, hatta en bireysel tutumlara kadar gidebilmekte ve ögretmen adaylarının ihtiyacına göre bir sonraki sunumda kullanılabilmektedir. Avrupa'daki yabancı dil öğretmenlerine yönelik başvuru çerçevesinin (Kelly ve diğerleri, 2004: 26-27) "Öğretmenlik Deneyimi için Aç̧ı bir Çerçeve" başlı̆̆ını taşıyan 3. maddesi "uygulama sırasında adaylara hem ana hatları içeren bir yönerge, hem de dönüt sunulmasının adaylar için önemi vurgulandıktan sonra "adayların hem okuldan (bilhassa kendilerini izleyen öğretmenden) hem de kendi kurumlarından yapılandırılmış bir dönüt almaları" ve "hem öğretmenlerin hem öğretim elemanlarının dönütlerinin yerinde ve yapıcı olması gerektiğine" dikkat çekilmektedir. 4. madde "öğretmenle çalışmak ve öğretmenin değerini takdir etmek" başlığı altında "öğretmenlerin öğretmen adaylarının yaptığı dersi gözlemlemesi ve kaydettiği gelişmelerle ilgili ayrıntılı dönüt vermesi" "ders planlarını incelemesi ve tavsiyelerde bulunarak desteklemesi” gerektiği belirtilmektedir. 
Tablo 6: Öğretim Elemanlarının Katılımı

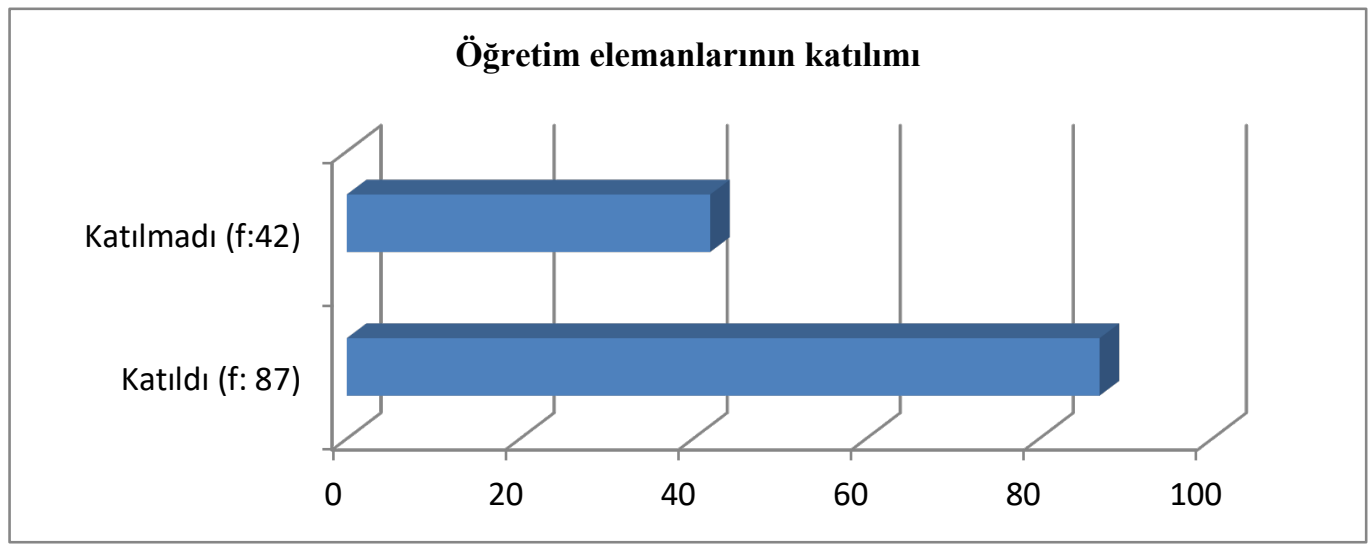

Tablo 6 uygulamadan sorumlu öğretim elemanlarının öğretmen adaylarının ders sunumlarına katılımları ile ilgilidir. Bu sorunun yanıtına göre gerçekten de adayların büyük çoğunluğunun (N:87) verdikleri derslere öğretim üyelerinin katıldığını belirtmesi sevindiricidir. Ancak öte yandan 42 aday verdiği derse öğretim üyesinin katılmadığını ifade etmiştir. Öğretmenlik Uygulama Yönergesi'nde (2018: 8) uygulama öğretim elemanının görev yetkilerine baktığımızda "her dönemde her bir uygulama öğrencisinin dersine en az dört kez fiilen katılır" denildiğini görmekteyiz.

Kukanauza de Mazeika (2001) mikro-öğretim üzerine yaptığı araştırmada akran geri bildiriminin bile öğretmen adaylarına geniş perspektifler sunduğunu, diğer bireylerin farklı bakış açılarını sunarak öğrenme sürecini zenginleştirdiğini belirtmektedir. Askew ve Lodge (2000) almaaktarma öğretme modelinde, dönütü öğretmenden öğrenciye bir "armağan" olarak tanımlamaktadırlar. Bu açıdan bakıldığında, öğretim elemanının vereceği dönütün adaya, kuramsal derslerinde edindiği öğrenmelerin nasıl uygulamaya geçirildiğini görme ve kuram ile uygulama arasında bir karşılaştırma yapma olanağı sunacak, dahası ona mesleği icraya hazır olma, eksiklerinin bilincine varma, kendini daha iyi tanıma açısından çok değerli fikirler verecektir. Zaman zaman Öğretim üyelerinin ders yoğunluğu, program çakışmaları, vb nedenlerle öğretmen adaylarının derslerini izleyememesi durumu ile karşılaşılmaktadır. Ancak öğretmen adayının yaptığının iyi olduğunu bilmeye ihtiyacı vardır. Ders programları yapılırken uygulama derslerinin de göz önüne alınması ve öğretim elemanlarının da uygulama derslerine katılmanın yararları konusunda bilinçlendirilmesi yerinde olacaktır.

Tablo 7: Dönüt Alma Sıklığı

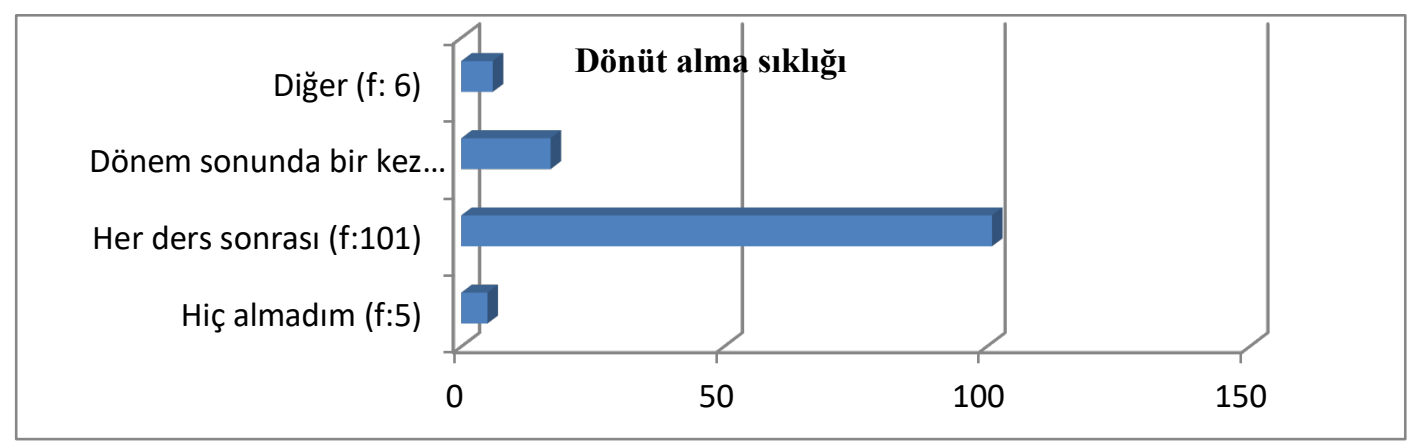

Grafik 7'de öğretmen adaylarının büyük çoğunluğunun (N:101) her dersten sonra dönüt aldıkları memnuniyetle görülmektedir. Yukarda sözünü ettiğimiz Öğretmenlik Uygulama 
Yönergesi’nde (2018) “öğretim elemanı (...) uygulama öğrencisine, uygulamanın hemen sonrasında uygulamaya yönelik dönütleri uygulama öğretmenleri ile birlikte ayrıntılı olarak verir" denmektedir. Nitekim dönütün etkili olması için "mümkün olan en kısa zamanda" (Hadji, 1989: 59) verilmesi gerekmektedir. Clariana, Wagner ve Rohrer Murphy (2000: 19) "makul zorluk derecesinde çoktan seçmeli sorular kullanan bilgisayar destekli dersler için, bir testten acil ve gecikmeli dönüt grupları arasında doğru cevabın hatırlanması konusunda benzerlikler olduğunu, hatta gecikmeli dönüt grubunun biraz avantajlı olduğunu" ortaya koymuştur. Nitekim Mason ve Bruning (2001: 10) ise Gaynor (1981) ve Roper (1977)'e dayanarak başarıları düşük olan öğrencilerin acil geri bildirimlerden, başarılı öğrencilerin ise gecikmeli dönütlerden daha iyi yararlanabileceğini gösterdiklerini söyledikten sonra, bu bulguların başarılı öğrencilerin önceki bilgilerinden yararlanma ve yanlış bilgiler üzerine yeniden düşünme yeteneği ile ilgili olabileceğini vurgulamaktadırlar Bosc-Miné (2014: 131) de aynı konuda "öğrenciler hedeflenen öğrenme alanında özerkleştikçe "öğretmenlerin daha az dönüt vermek durumunda kaldıklarını" ifade etmektedir. Gerçekten de tekrar etmek öğrenmenin temel anahtarlarından biridir. Bu nedenle sunum sayısının çok olması öğretmen adayının kaydettiği ilerlemeyi görmek bakımından ilginçtir.

Tablo 8: Dönüt Türü (yazıl1-sözlü)

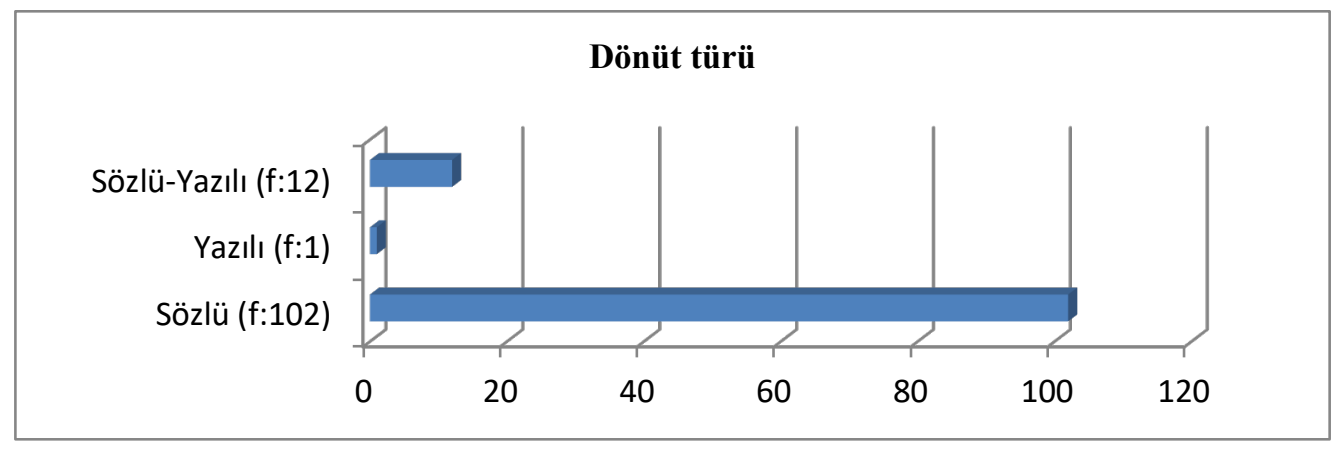

Dönütün türü de öğrenmeyi etkilemektedir. Grafik 8 öğretmen adaylarının çoğunluğunun (N:102) sözlü dönüt aldığını, 12 adayın hem yazılı hem sözlü dönüt aldığını 1 adayın ise sadece yazılı dönüt aldığını göstermektedir. Uygulama sunumları sırasında adaya müdahale etmemek, sözünü kesmemek, sunumdan sonra dönüt vermek daha yararlı olacaktır. Ancak dönütün etkililiğini artırmak için dönüt araçları çoğaltılmalı, yazılı, sözlü dönütlerin yanı sıra teknolojinin çok ilerlediği günümüzde ses ve görüntü kayıtları yapılarak da dönüt verilmelidir.

Tablo 9: Dönüt türü (olumlu-olumsuz)

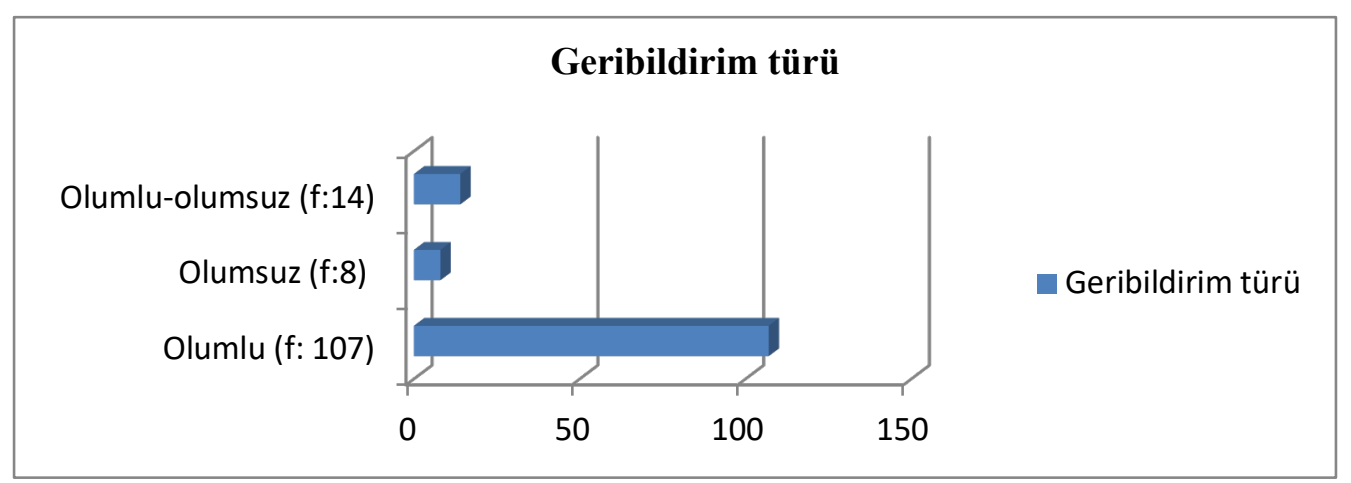


Grafik 9 öğretmen adaylarının büyük çoğunluğunun (N:107) olumlu, 14'ünün hem olumlu hem olumsuz, 8'inin de olumsuz geri bildirim aldığını göstermektedir. Geri bildirim gerçekten de yetiştirici değerlendirmenin (Scriven, 1967) en temel öğesidir. Askew ve Lodge (2000 s. 7) olumlu ve olumsuz dönütün güdüleme üzerine etkilerini şu şekilde belirtmektedirler : "olumlu" dönüt öğrenmeye yardımcı olduğu ölçüde olumludur. Olumlu dönüt öğrenende güveni artırarak, yeni anlamlandırmalar sağlayarak, öğrenmeyi artırarak, yeni ilişkiler ve bağlantılar kurmaya yardım ederek güdülemeyi artırabilir. Olumsuz dönüt ise yargılayıcı ve eleştirel tavırla cesaretini kırarak, muğlak ve çelişkili mesajlar vererek ve ilerlemeyi değerlendirmek için başkalarına bağımlılığı teşvik ederek güdülemeyi düşürebilir.

Olumlu geri bildirim başarıya odaklanan, bireyi zenginleştiren, onun kendine saygısını artıran, ona güven veren bir dönüt türüdür. Olumlu geri bildirim içsel güdülenmeyi artırmaktadır (Deci \& Ryan, 1985: 60-61). Buna karşılık yapılmaması gerekeni vurgulayan, yanlış1 ön plana çıkaran, öğrencinin kendisine saygısını zedeleyen (Bond, 1995) olumsuz dönütün mümkün olduğunca kullanılmaması, ancak düzeltici seçenekler sunularak öğrenmenin gelişiminin teşvik edilmesi önerilmektedir.

Dönüt verirken adını Joseph Luft et Harrington Ingham'dan (1955) alan ve kişilerarası ilişkileri anlamak için etkili bir araç olan Johari Penceresi'nin göz önünde bulundurulmak yararlı olabilir. Böylece öğretmen adayının kendi kendini daha iyi tanımasına da yardımcı olunabilir.

Ayrıca dönüt elden geldiğince bireyselleştirilmeli ve belli bir çalışmanın, olgunun belli bir yönüne odaklanmalıdır. Black ve Wiliam'e göre (1998: 9) geribildirimin öğrencinin yaptığ 1 çalışmanın belli nitelikleri konusunda öğrenciye kendisini nasıl geliştireceği konusunda öğütler verilerek yapılmalı ve dönüt verilen öğrenciyi diğer öğrencilerle karşılaştırmaktan kaçınmalıdır.

Tablo 10: Öğrencilerin dönütle ilgili ölçekten almış oldukları ortalama puan düzeyleri

\begin{tabular}{lc}
\hline Faktör & Xort \\
\hline Kayg1 & 2,63 \\
\hline Mesleki gelișim & 4,36 \\
\hline
\end{tabular}

Öğretmen adaylarının dönütle ilgili ölçekten almış oldukları puanlar ise Tablo 1'de gösterilmektedir. Tablo 1 incelendiğinde öğretmen adaylarının kaygı düzeylerinin düşük olduğu görülmektedir. Buradan genel olarak olumlu veya olumsuz olsun, sözlü ya da yazılı olsun, geribildirimlerin adaylarda endişe yaratmadığı, onların güdülenmesini düşürmediği, aksine bir sonraki sunumlarını planlamada, yöntem ve stratejilerini belirlemede kolaylık sağladığı gibi olumlu düşüncelere sahip oldukları söylenebilir.

Ayrıca mesleki gelişim düzeyleri açısından bakıldığında, elde edilen bulgular bu faktörün yüksek olduğunu göstermektedir. Adayların öğretim deneyimleri ile ilgili dönüt almanın kendilerinde farkındalık yarattığı, zayıf ve güçlü yönlerini görmelerine katkı sağladığı, başarılarını etkilediği görüşünde oldukları memnuniyetle görülmüştür. Öte yandan arkadaşlarının yanında dönüt verilmesinin kendilerini rahatsız etmediğini belirtmişlerdir.

\section{Sonuç ve Öneriler}

Bu çalışmada Eğitim Fakültesi dışında yabancı dil eğitimi veren fakültelerden mezun olup öğretmen olmak üzere 2017-2018 öğretim yılında bir eğitim fakültesinde pedagojik formasyon eğitimi alan yabancı dil öğretmen adaylarının uygulama dersleri kapsamında aldıkları dönüt konusundaki görüşleri belirlenmiştir. 
- Öğretmen adaylarının büyük çoğunluğu (N:88) haftada 4 saatten fazla derse devam ettiğini belirtmiş̧tir. 45 öğrencinin haftalık ders izleme saati 4 ten azdır.

- Öğretmen adaylarının büyük çoğunluğu (N:65) 4 saatten fazla ya da en az 4 saat (N:25) sunum yapmıştır. Ancak 39 öğrenci 4 saatten daha az sunum yapmıştır.

- Öğretmen adaylarının büyük çoğunluğu (N:122) verdikleri dersin uygulama öğretmenleri tarafından izlendiğini, 7 öğrenci ise uygulama öğretmeni tarafından izlenmediğini belirtmiştir.

- Öğretmen adaylarının büyük çoğunluğu (N:101) her dersten sonra dönüt almıştır. 11 öğrenci dönüt almadığını ifade etmiştir.

- Öğretmen adaylarının büyük çoğunluğu (N:102) sözlü, 12 öğretmen adayı yazıllı, 1 öğretmen adayı ise hem yazılı hem sözlü dönüt aldığını belirtmiştir.

- Öğretmen adaylarının büyük çoğunluğu (N:107) olumlu dönüt almıştır. Olumsuz geri dönüt alanların sayısı 8 'dir. 14 öğretmen adayı hem olumlu hem olumsuz dönüt aldığını belirtmiştir.

- Öğretmen adaylarının büyük çoğunluğu (N:87) öğretim üyelerinin ders sunumlarına katıldığını, 42 öğretmen adayı ise katılmadığını belirtmiştir.

Öğretmen adaylarına nitelikli bir eğitim hizmeti sunmak öğretmen eğitiminin öncelikli hedefleri arasında yer almaktadır. Çünkü onların eğitiminin iyi olması gelecek kuşakların iyi bir eğitim alması demektir. Nitelikli bir öğrenme sürecinin en önemli öğelerinden biri de dönüttür. Dönüt verme sürecinin yararlı olması her şeyden önce onun amacının ve öneminin taraflarca iyi kavranmasını, bu sürecin bir ölçme değerlendirme süreci gibi değil, geliştirici bir süreç olarak telakki edilmesini gerektirir.

Uygulama öğretim elemanı olarak izlediğimiz öğretmen adaylarının orta öğretim kurumlarında yaptıkları sunum ve derslerde öğrencilerine dönüt vermekte zorlandıklarına tanık olmaktayız. Öğrencilerin yanıtı doğru olsun yanlış olsun öğretmen adayının bu yanıtı ya duymadığını ya da duymazdan geldiğini gözlemliyoruz. Avrupa'daki yabancı dil öğretmenlerine yönelik başvuru çerçevesinin (Kelly ve diğerleri, 2004: 73) "stratejiler ve beceriler" bölümünde, 29. maddede "arkadaşlarını gözlemleme ve değerlendirme teknikleri eğitimi” başlı̆̆ altında, öğretmen adaylarının birbirini gözlemleyip değerlendirmesi konusunda eğitim almalarının, onların "uygun ve yapıcı dönüt vermek, kendilerininkinden farklı yaklaşımları değerlendirmek ve mesleki dayanışma duygusu geliştirmek" açısından önemli olduğu vurgulanmakta ve "öğretmen adayları uygun bir dil ve söylem kullanarak dengeli ve eleştirel bir dönüt vermeyi öğrenirler" denilmektedir. $\mathrm{O}$ halde öğretmen adaylarının hem birbirlerine hem de öğrencilerine dönüt verebilmesi için bu konuda eğitim almış olması gerekir. Bu konuda kuramsal araştırma çalışmaları yapmış olmaları da çalışmalarının sonuçlarını pratiğe geçirmelerini kolaylaştıracaktır. Nitekim bu konuda da Avrupa'daki yabanc1 dil öğretmenlerine yönelik olarak başvuru çerçevesinin 31. maddesinde (Kelly ve diğerleri, 2004: 74-75), "Eyleme Dayalı Araştırma Eğitimi" başlığı altında "araştırma projelerinin düşünme ve sorgulama yaklaşımını teşvik ettiği ve öğretmen adaylarına zor sorunları çözme konusunda değerli bir kuramsal çerçeve sunduğu" belirtildikten sonra, "[Eyleme dayalı araştırmanın] öğretmen adaylarına değerlendirme, yayma ve arkadaşlarından dönüt istemenin araştırma sonuçlarının pratiğe geçirilmesine nasıl katkı sağladığını gösterir" denilmektedir.

Avrupa'daki yabancı dil öğretmenlerine yönelik olarak hazırlanan başvuru çerçevesi stajlarda öğretmen adaylarına rehberlik edecek öğretmenlerin de bu konuda eğitim almış olmalarına dikkat çekmekte ve bu görevi üniversiteye vermektedir (Kelly ve diğerleri, 2004: 43). Nitekim 12. Madde "Öğretmenler için Öğretmen Adaylarına Rehberlik Edecek bir Eğitim” başlığ altında "üniversitelerin ya da öğretmen eğitimi veren kurumların (...) okullardaki öğretmenlerin yapıcı bir dönütün farklı biçimleri" üzerine "ayrıntılı bilgi ve uygun bir eğitim almış olduklarından emin olması gerektiğini vurgulamaktadır. O halde gerek okuldaki öğretmenlerin, gerekse öğretmen 
adaylarının dönüt konusunda bilinçlendirilmesi, kuramsal derslerde dönüt üzerinde durulmas1, mikro-öğretim çalışmalarıyla öğretmen adaylarına uygulamalar yaptırılması ve onların ortaöğretimdeki Okul Deneyimi ve Öğretmenlik Uygulaması dersleri kapsamında öğrencilerine ne zaman ve nasıl dönüt verecekleri konusunda eğitilmesi yararlı olacaktır.

Öte yandan öğretmen adaylarına verilen dönütün çoğul olması, hem öğretmen hem öğretim üyesi, hem akranlar, hem de teknolojik olanaklar gibi farklı kaynaklardan gelmesi tercih edilmektedir. Günümüzde teknoloji hızla gelişmekte, başvuru ve bilgi kaynakları çeşitlenmekte, güvenilir kaynak seçimi giderek daha çok önem kazanmaktadır. Bilginin çeşitliliği karşısında eğitimin ve eğitim kurumlarının rolü de değişmektedir. Yabancı dil öğretmenlerinin eğitimi için Avrupa başvuru çerçevesinin (Kelly ve diğerleri, 2004: 24-25) 2. maddesi "Hizmet-öncesinde ve Hizmet-içinde Sunulan Eğitimin Esnek ve Modüler olarak Düzenlenmesi" başlığı altında "dersler sanal ortamlarda öğretmen adaylarına açık olduğu takdirde adayların hem ders hem dönüt alabileceği”" belirtilmektedir. Günümüzde ekranlar giderek kitabın, defterin, kâğıdın yerini aldığına göre öğretmen adayına sanal ortamlardan da güvenilir bilgi sunmak, özdeğerlendirme yapmasını ve dönüt almasını teşvik etmek onun başdöndürücü değişimle baş edebilmesine yardımcı olacaktır.

Çalışmamızın ilgi çekici yanlarından biri de eğitim sistemimizdeki tekdilliliği ortaya çıkarmasıdır. Orta öğretim kurumlarında İngiliz dili öğretimi dışındaki dillerde öğretmenlik uygulaması yapmak durumunda olan diğer dillerin öğretmen adaylarının haftalık ders sayısını tamamlamakta zorlandığı görülmektedir. Yukarıda da söylediğimiz gibi tüm dünyada hareketlilik artıkça çokdillilik ve çokkültürlülük ihtiyacı da artmaktadır (Yüce, 2019b). Ülkemizin de bu duruma ayak uydurması beklenmektedir. Yabancı dil denildiğinde, Milli Eğitim Bakanlığı'nın 2023 Vizyonu'na (MEB 2018) bakıldığında da görüleceği gibi hala sadece İngilizce'nin akla gelmesi düşündürücüdür. Avrupa Konseyi'ne kurulduğundan beri üye olan ve gelişmelerini yakından izleyen ülkemizin eğitim ve dil politikasını çok dillilik üzerine kurması ve daha fazla yabancı dil arzı getirmesi orta öğretimde uygulama yapacak öğretmen adaylarına da firsat eşitliği sunacaktır.

Günümüzde teknoloji sayesinde bilgi kaynaklarına erişim çok gelişmiş ve kolaylaşmıştır. Ancak ders kitaplarımızı ve müfredat programlarımızı şöyle bir gözden geçirdiğimizde ön sırayı Bloom'un (1956) hedeflerinin ilk aşamalarındaki alt düzey bilişsel yeterliliklerin, yani bilgi, kavrama ve uygulamanın aldığı görülmektedir. $O$ halde okulun ve eğitimin amacı öğrenciye başka yerlerde kolayca bulabileceği bilgiler sunmaktan öte, onun bilgiyi en iyi şekilde özümsemesini sağlamaktır. Montaigne (1595) çocuğun eğitilmek üzere teslim edileceği öğretmenin "bilgi dolu değil akıl dolu bir kafaya sahip olmasıni“" tercih ettiğini ifade eder. Öğretmen adayını yetiştirmekten ziyade notlamaya yönelik olan üniversitelerdeki sınav sisteminde, öğrencilerin nota ve sonuca odaklandığı, öğrenme süreciyle, dönütle, yorumlarla pek ilgilenmediği gerçektir. Nitelikli bir eğitimin olmazsa olmazı dönütlerle güçlendirilmiş yetiştirici ya da biçimlendirici sınavlardır. Çünkü dönüt ile bilgi arasındaki fark bilginin tek yönlü ve dikey olmasıdır. Dönüt ise ister armağan, ister pinpon, ister çevrim/diyalog olsun, iletişimdir, yataydır, çift yönlüdür. Yapıc1 ve etkili olduğu ölçüde çok değerli ve yararlı bir öğrenme aracıdır.

Öte yandan her türlü değerlendirmenin ceza değil rehber olduğunu unutmamak gerekir. Dönütün yararlı ve etkili olması için dönüt verilen kişinin duygu ve tepkilerini dikkate almalıdır. Gerekirse olumsuz dönütler baş başa, olumlu dönütler herkesin önünde verilebilir. Ancak öğretmen adaylarınının zamanla birbirlerinden dönüt almaya hazır olması gerekir. Yorumlarda kısa, öz, nazik, içten, yapıcı, iyi niyetli olmak, kişilik üzerine özcü ve genelleyici yaklaşımlardan kaçınmak, belli bir olguya, bir davranışa odaklanmak, yanlışı öğrenme sürecinin bir bileşeni kabul etmek gerekir. Olumlu noktalardan başlamak daha sonra çalışılması ve geliştirilmesi gereken noktalara değinmek ve son olarak teşvik ve cesaretlendirmek, öncelikle adayın güçlü yönlerini vurgulamak, eksikleri üzerine düşündürmek, kendi kendini düzeltmesine firsat vermek ve görüşlerini dinlemek için belli bir zaman ayırmak yararlı olacaktır. 


\section{Öneriler}

Öncelikle dönüt türlerinin artırılması, çeşitli kaynaklardan dönüt alınması yararlı olacaktır. Öğretmen adayının önce kendi yaptığı etkinlik üzerine düşünmesi, daha sonra akranlarından, öğretmenden ve öğretim elemanından dönüt alması, gerekirse teknolojik olanaklardan yararlanması uygun olacaktır. Bazen akran dönütü diğer tüm dönütlerden daha etkili olabilmektedir.

Dil ve eğitim politikamızın çok dillilik açısından gözden geçirilmesi, çok küçük yaşlardan itibaren çok dilliliğin ve çok kültürlülüğün benimsenmesi, orta öğretimde sunulan dillerin çeşitlendirilmesi ve İngilizce'nin dışında ikinci yabancı dil olarak sunulacak derslerinin saatlerinin artırılması yararlı olacaktır. Üniversitelerde farklı dillerde eğitim aldıktan sonra bu dillerin öğretmeni olmak üzere eğitim fakültelerine pedagojik formasyon yapmak üzere kabul edilen öğretmen adaylarının hem stajlarını rahatlıkla yapmalarına olanak verecek, hem de istihdam olanakları sunacaktır.

Son olarak yalnız uygulamada değil kuramsal derslerde de dönüt verilmesi eğitimin etkililiğini, niteliğini artıracaktır. Öğretim üyelerinin ve öğretmen adaylarını izleyen öğretmenlerin dönüt konusunda bilinçlendirilmesi sağlanmalıdır. Bu konuda öğretim elemanları nezdinde yapılacak bir soruşturma ilginç veriler sunabilir.

\section{Kaynakça}

Akkuzu, N. (2012). Kimya öğretmen adaylarını mesleki yeterlilik düzeylerinin belirlenmesi (Doktora Tezi). Dokuz Eylül Üniversitesi Eğitim Bilimleri Enstitüsü.

Akkuzu, N. ve Uyulgan, M. A. (2014). Toward making the invisible visible using a scale: prospective teachers' thoughts and affective reactions to feedback. Irish Educational Studies, 33(3), 287-305. https://doi.org/10.1080/03323315.2014.923184

Ananthakrishnan, N. (1993). Microteaching as a vehicle of teacher training--its advantages and disadvantages. Journal of Postgraduate Medicine, 39(3), 142-143.

Arslan, A. (2016). Öğretim Stratejileri ve öğrenme stratejileri (Öz düzenlemeli Öğrenme). T. Yanpar Yelken (Ed.), Öğretim İlke ve Yöntemleri, Anı Yayınları, 185-222. https://doi.org/10.14527/9786052416990.03

Askew, S. ve Carnell, E. (1998). Transforming learning: Individual and global change. Cassell.

Askew, S. ve Lodge, C. (2000). Gifts, ping-pong and loops - linking feedback and learning in Feedback for learning, S. Askew (ed.). Routledge / Falmer. 1-17. https://doi.org/10.4324/9780203017678

Bandura, A. (1997). Self-efficacy: The exercise of control. W. H. Freeman and Company.

Black, P. and Dylan W. (1998) 'Assessment and Classroom Learning', Assessment in Education: Principles, Policy \& Practice, 5:1, 7 - 74. http://dx.doi.org/10.1080/0969595980050102

Bloom, B. S. (Ed)(1956). Taxonomy of Educational Objectives, Handbook I: The Cognitive Domain. Longman.

Bloom, B. S. (1968). Learning for Mastery, Evaluation Comment, 1 (2). Reprint from Evaluation Comment, University of California, Center for the Study of Evaluation of Instructional Programs, May, 1968. https://files.eric.ed.gov/fulltext/ED053419.pdf

Bloom, B. S. (1971). Mastery learning. In J. H. Block (Ed.), Mastery learning: Theory and practice. Holt, Rinehart \& Winston, 47-63. 
Boud, D. ve Molloy, E. (2013) Rethinking models of feedback for learning: the challenge of design. Assessment \& Evaluation in Higher Education, 38(6), 698-712. https://doi.org/10.1080/02602938.2012.691462

Bosc-Miné, C. (2014). Caractéristiques et fonctions des feed-back dans les apprentissage. L'Année psychologique, 114 (2), 315-353. https://doi.org/10.4074/S000350331400205X.

Bransford, J., Derry, S., Berliner, D. ve Hammer-ness, K. (2005). "Theories of learning and their roles in teaching" Preparing teachers for a changing world: What teachers should learn and be able to do. Jossey-Bass, 40-87.

Brophy, J. E. ve Good, T. L. (1970). Teachers' communication of differential expectations for children's classroom performance: Some behavioral data. Journal of Educational Psychology, 61(5), 365-374. https://doi.org/10.1037/h0029908

Butler, D. L. ve Winne, P. H. (1995). Feedback and Self-Regulated Learning: A Theoretical Synthesis. Review of Educational Research, 65, 245-281. https://doi.org/10.3102/00346543065003245

Caroll, J. B. (1963). A model of school learning. Teachers College Record, 64 (8), 723-733.

Carroll, J.B. (1989). The Carroll Model: A 25-Year Retrospective and Prospective View, Educational researcher, 18(1), 26-31. https://doi.org/10.3102/0013189x018001026

Carless, D. (2006). Differing perceptions in the feedback process. Studies in Higher Education, 31(2), 219-233. https://doi.org/10.1080/03075070600572132

Carless, D. (2009). Trust, distrust and their impact on assessment reform. Assessment \& Evaluation in Higher Education, 34(1), 79-89. https//doi.org/10.1080/02602930801895786.

Carless, D., Salter, D., Yang, M. ve Lam, J. (2011). Developing sustainable feedback practices. Studies in Higher Education, 36(4), 395-407. https://doi.org/10.1080/03075071003642449

Charte européenne des langues régionales ou minoritaires (1992). https://rm.coe.int/168007c07e. https://doi.org/10.3406/mots.1997.2473

Clariana, R. B., Wagner, D. ve Roher-Murphy L.C. (2000). Applying a Connectionist Description of Feedback Timing. Educational Technology Research and Development, 48(3), 5-22. https://doi.org/10.1007/bf02319855

Conclusion de la présidence, Conseil Européen de Barcelone, 15 et 16 Mars 2002. https://www.consilium.europa.eu/media/20935/71026.pdf

Coste, D. (1991). Diversifier, certes ..., D. Coste \& J. Hébrard (éds) : Vers le plurilinguisme? Ecole et politique linguistique [Özel say1], Le français dans le monde, Recherches et applications, Hachette, 170-178. https://doi.org/10.1017/s027226310001144x

Çimer, S.O., Bütüner, S.Ö. ve Yiğit, N. (2010). Öğretmenlerin Öğrencilerine Verdikleri Dönütlerin Tiplerinin ve Niteliklerinin İncelenmesi. Uludağ Üniversitesi Ĕ̆itim Fakültesi Dergisi, 23(2), 517-538. https://doi.org/10.19171/uuefd.11636

Deci, E. L.ve Ryan, R. M. (1985). Cognitive Evaluation Theory Perceived Causality and Perceived Competence. Intrinsic Motivation and Self-Determination in Human Behavior içinde. New York: Plenum Press, 43-85. http://dx.doi.org/10.1007/978-1-4899-2271-7.

Dehaene S. (2018). "Les 4 pilliers de l'apprentissage, ce que nous disent les neuro-sciences", La Révolution de l'Education Paris Innovation Review, 17-27.

Ekşi, G. (2012). Implementing an observation and feedback form for more effective feedback in microteaching. Education and Science 37(164), 267-282. 
Epstein, S. (1993). Emotion and self-theory. M. Lewis \& J. M. Haviland (Eds.), Handbook of emotions. Guilford Press, 313-326.

Ferry L. (2017). Sur le classement PISA. https://www.youtube.com/watch?v=D16DGntKVEc

Gaynor, P. (1981). The effect of feedback delay on retention of mathematical material. Journal of Computer Based Instruction, 8, 28-34.

Georges, F. ve et Pansu, P. (2011). Les feedbacks à l'école: un gage de régulation des comportements scolaires. Revue française de pédagogie 176, 101-124. https://doi.org/10.4000/rfp.3239

Goleman, D. (1996). Emotiona Intelligence: Why it Can Matter More Than IQ? Bloomsbery Publishing.

Goullier, F. (2006). Les outils du Conseil de l'Europe en classe de langue. Didier.

Hadji, Ch., (1989). L'évaluation, règles du jeu. Des intentions aux outils. ESF.

Hell-Nieuwenhuis, M. van (2012). Le feedback en classe de langue: combien, quand, comment et avec quel rendement? Mémoire de Master, Université d'Utrecht. https://dspace.library.uu.nl > handle > SCRIPTIE 2012.

Hounsell, D. (2007). Towards More Sustainable Feedback to Students. In: Falchikov, N. and Boud, D., Eds., Rethinking Assessment in Higher Education. Routledge, 101-113.

Hounsell, D., McCune, V., Hounsell, J. and Litjens, J. (2008) The quality of guidance and feedback to students, Higher Education Research \& Development, 27(1), 55- 67.

https://doi.org/ 10.1080/07294360701658765

Kelly, M., Grenfell, M., Allan, R., Kriza, C. ve McEvoy W., (2004) European Profile for Language Teacher Education - A Frame of Reference. Final report. A report to the European Commission Directorate General for Education and Culture Brussels.

Kukanauza de Mazeika, J. M. (2001). Effect of different types of feedback during microteaching sessions on preservice teachers. Doctoral Dissertation, New York University.

Lyster, R. ve Ranta, L., (1997) Corrective feedback and learner uptake: negotiation of form in communicative classroom. Studies in Second Language Acquisition 19(1), 37-66. https://doi.org/10.1017/S0272263197001034.

Luft, J. ve Ingham H. (1955). The Johari window: A graphic model of interpersonal awareness. Proceedings of the western training laboratory in group development. Los Angeles: University of California.

Mason, B.J. ve Bruning, R., Providing feedback in computer-based instruction : What the researc tell us. https://www.researchgate.net/publication/247291218 Providing Feedback in Computerbased_Instruction_What the Research_Tells_Us.

MEB, 2023 Eğitim Vizyonu (2018). http://2023vizyonu.meb.gov.tr.

Montaigne, Michel de (1595). Essai, Livre I, chapitre XXV, « De l'institution des enfants », \&16. Traduction en français moderne du texte de l'édition de 1595 par Guy de Pernon 2009.

Morrow, V. (2008). Ethical dilemmas in research with children and young people about their social environments. Children's Geographies, 6(1), 49-61, https://doi.org/10.1080/14733280701791918. 
O’Donovan, B., Rust, C. \& Price, M. (2016) A scholarly approach to solving the feedback dilemma in practice, Assessment \& Evaluation in Higher Education, 41(6), 938949, https://doi.org/10.1080/02602938.2015.1052774

Öğretmenlik Mesleği Genel Yeterlikleri (2017). Öğretmen Yetiştirme ve Geliştirme Genel Müdürlüğü. https://doi.org/10.16992/asos.14478

Pavlov, I. P., Gantt, W. H.ve Volbort, G. V. (1928). Lectures on conditioned reflexes: Twenty-five years of objective study of the higher nervous activity (behavior) of animals. New York: International Publishers. https://doi.org/10.1037/11081-000

Paquette, G. (1987). Feedback, rétroaction, rétroinformation, réponse... du pareil au même. Communication \& Langages, 5-18, https://doi.org/10.3406/colan.1987.984

PISA 2018 results. https://www.oecd.org/pisa/publications/pisa-2018-results.htm

Pressey, S. L. (1932). A third and fourth contribution toward the coming "industrial revolution" in education. School and Society, 36(934), 668-672.

Profil européen pour la formation des enseignants de langues étrangères - un cadre de référence.

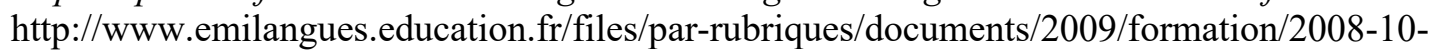
29_Kelly_Report_fr_.pdf https://doi.org/10.4000/ries.1420

Puren C., Bertocchini P. ve Costanzo, E. (1998) Se former en didactique des langues. Ellipses.

Roper, W., J. (1977) Feedback in Computer Assisted Instruction, Programmed Learning and Educational Technology, 14(1), 43-49. https://doi.org/10.1080/1355800770140107.

Saban, A. ve Çoklar A.N. (2013). Pre-Service Teachers' Opinions about the Micro-Teaching Method in Teaching Practice Classes. The Turkish Online Journal of Educational Technology - April 2013, 12(2), 234-240.

Scriven, M. (1967). The methodology of evaluation. American Educationel Research Association.

Skinner B. F., (1958). Teaching Machines, Science, 128 (3330), 969-977. https://doi.org/10.1126/science.128.3330.969

Thorndike, E. (1932) The Fundamentals of Learning.Teachers College Press.

Watson, J. B. (1928). The ways of behaviorism. Harper \& Bros.

Watson, J. B. (1930). Behaviorism. University of Chicago Press.

Wiener, N. (1948). Cybernetics or Control and Communication in the Animal and the Machine. Hermann \& Cie Edieurs, The Technology Press, John Wiley \& Sons. Inc.

Wiener, N. (1950). The Human Use of Human Beings. Cybernetics and Society. 1985.

Womer, F. B (1970). What is National Assessment? https://files.eric.ed.gov/fulltext/ED067394.pdf.

Yüce, E. (2019 a). EPOSTL: Revisiting the roles of language teachers at a recently established

ELT department. International Online Journal of Education and Teaching, IOJET, 6(1), 233243.

Yüce, E. (2019 b). Plurilingualism and Pluriculturalism in the CEFR Companion Volume). IJOPEC

Publication Limited, Editör:Tahir Balc1, Ali Osman Öztürk, Ergün Serindag. 